\title{
Institutional performance and new product development value chain for entrepreneurial competitive advantage
}

\author{
P. Eko Prasetyo ${ }^{a^{*}}$ and Fuad Zainul Dzaki ${ }^{\mathrm{b}}$
}

${ }^{a}$ Professor in Faculty of Economics, Universitas Negeri Semarang, Indonesia ${ }^{b}$ Faculty of Economics and Business, Gadjah Mada University Yogyakarta, Indonesia

\section{H R O N I C L E}

Article history:

Received January 2, 2020

Received in revised format June

8, 2020

Accepted July 172020

Available online

July 172020

Keywords:

Value chain

New product development

Institutional performance

Competitive advantage

Entrepreneurship

\section{A B S T R A C T}

This study explains the role of institutional performance and new product development (NPD) value chain strategies to enhance entrepreneurial competitive advantage. The analysis was based on survey data on 125 entrepreneurial households, taken using the multi-stage random sampling technique in Central Java and Yogyakarta. The path analysis model is used to explain the role and strategy used quantitatively. It was supplemented by a value chain analysis (VCA) model based on a supply chain management (MSC) approach in a more classical, linear, complex, and descriptive sub-sector analysis. The results show that the NPD factors significantly contribute to increasing the entrepreneurial competitive advantage. Furthermore, the NPD value chain strategy, apart from benefiting managers, provides employment opportunities and new markets to the community holistically. Its chain strategy changes the role and atmosphere of people's lives more humane.

C 2020 by the authors; license Growing Science, Canada.

\section{Introduction}

A smart and connected product requires a fundamental design rethink (Porter, 2015). According to Michael E. Porter (2015), at the most basic level, new product development (NPD) shifts from mechanical to true interdisciplinary system engineering. The new capabilities of this product change every activity in the value chain (Porter, 2015; Abdullah \& Senan, 2019). However, economic geography in the era of global competition involves paradox (Porter, 2000). Clusters may represent new ways of thinking about national, state, and local economies. There is a need for companies, governments, and other institutions to enhance competitiveness. Therefore, every organization requires an Augmented Reality strategy (Porter, 2019). Technology is the best way to produce new products (Prasetyo, 2020a). NPD is the output produced by technological advancements. Innovation and institutional performance can be used in managerial decisions for sustainable entrepreneurial competitive advantage and quality economic growth (Prasetyo, 2020a, 2020b, 2020c, 2019b). A competitive advantage in the global economy is increasingly dependent on local matters, knowledge, relationships, and motivation unmatched by global rivals, (Porter, 1998, 1985). The role of entrepreneurship and institutional performance in a region is critical for the prosperity of workers and the socio-economic community. Therefore, entrepreneurships should pay attention to the supply and value chains, economically and socially, to achieve competitive advantage and shared prosperity. In general, managers have the responsibility to ensure workers' welfare throughout the product supply chain, and that marketing meets the expected standards. Furthermore, institutional performance and entrepreneurs have a shared duty and responsibility to carry out all value chain activities to create an entrepreneurial competitive advantage for society's welfare. This study focuses on how the NPD value chain activity strategy can be conducted to improve the entrepreneurial competitive advantage continuously. It is based on empirical problems and the basis of strategy theory, which stated that to be successful,

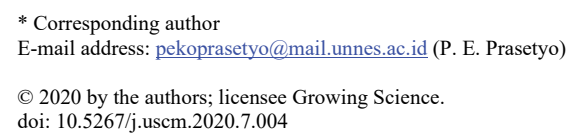


companies should create special value propositions that fulfill the needs of selected customers (Porter, 2011). NPD is considered to have a special value that can be developed from total product growth.

This study academically explains the changing role of supply chains for an entrepreneurial competitive advantage strategy. Its novelty and originality focus on the sub-strategy of creating value chains through managerial decisions, which is integrated with the institutional economic performance of local communities. The study's general purpose is to determine how the connected NPD intelligence changes the way managers work. It assesses how related institutional performance should be integrated to have the best strategy and collaboration. Furthermore, the value chain analysis model aims to achieve entrepreneurial competitive advantage in a region. This work provides a unique insight into the value creation in NPD, especially in the local entrepreneurship sector. It focuses on new ways of thinking about growth and competitiveness from small companies and networks in some regions (Asheim, 2018; Di Maria, 2019).

\section{Literature Review}

The basic concepts of the value chain and competitive advantage were first introduced by (Porter, 1985). The value chain analysis (VCA) explains the activity of a product's movement from the initial to the final production process to the consumer with many central values and supporters (Porter, 1985). Value chains are potential sources of product or service differentiation offered by organizations, and can be used to formulate the best and effective strategies from various testing interactions between entrepreneurs to gain competitive advantage (Ensign, 2001; Grigorescu, 2015; Zamora, 2016). The VCA model explains the globalization of the production paradigm (Ridley, 2009). Developing countries need to integrate SMEs into the Global Value Chain (GVC) and acknowledge the importance of governance in assessing industry performance from a value chain perspective (Gereffi, 2016, 2013; Zhang, 2014). This move can be referred to as a global commodity chain, global production network, or international supply chain (Gereffi, 2016, 2013).

The value chain provides an excellent framework for assessing opportunities for the poor in the livestock market (McDermott, 2010). The value chain is holistically useful in examining the potential market opportunities for small farmers and highlighting various technical, economic, and institutional constraints needed to be addressed by public policy (McDermott, 2010). According to OECD (2013), the value chain is a series of company activities involved in bringing products to the market from conception to end-use, including design, production, marketing, logistics, and distribution. Various companies use this VCA approach to understand segments, distribution channels, price points, product differentiation, sales propositions, and value chain configurations with the most significant competitive advantage (IMA, 1996). Entrepreneurships conduct VCA by examining each step of production needed to make products superior. The aim is to optimize all activities that lead to competitive advantage and high-profit levels. Companies need to recognize their position in the value chain and opportunities to create value in a more competitive environment (Simatupang, 2017). In the current market, supply chains compete with the value chain for competitive advantage. Therefore, it is vital to include competitive strategies in the company's value chain (Vijayan, 2016). This transcends product differentiation into operational differentiation and strategies (Porter, 2019; Vijayan, 2016; Doan, 2020). The NPD value chain strategy is chosen to fulfill customer needs since it improves employees' welfare. This is achieved through shared value activities created between entrepreneurial managers and related institutional performance.

According to strategy theory, companies should create special value propositions that fulfill the needs of selected customers to be successful (Porter, 2011). According to Michael E. Porter (2011), a company gains competitive advantage by configuring a series of activities to create, produce, sell, deliver, and support its products or services. Furthermore, (Porter, 2011), established that for decades, entrepreneurs have studied positioning and the best way to design activities and their integration. However, opportunities to fulfill basic community needs have been ignored. The community impacts and weaknesses affecting the value chain have also been misunderstood (Porter, 2011). Business model innovation is a source of sustainable competitive advantage (Bashir, 2017). The VCA model can be adapted to include additional perspectives that combine shared values and look beyond internal value chain stakeholders with collaboration for sustainable competitive advantage (Porter, 2011). The basic concepts of the value chain and competitive advantage theory is well established and can be used as a theoretical basis in this study. Meanwhile, the relationship between economic institutions and social progress still depends on the aspect of social progress being analyzed (Porter, 2019). Neoclassical institutional economics explains how and why individuals obtain social characteristics without the help of social relations or structures (Agboola, 2015; Madra, 2017; Steinhauser, 2014). However, the theory has a different concept in the market, institutional failure, transaction costs, information asymmetry, diversity of motivations, cognitive limitations, strategic behavior, and evolution (Madra, 2017). Economists have tried to change concepts and methodologies to complement and improve this theory (Madra, 2017; Madra, 2017; Prasetyo, 2020b). They are attracted to the fate of neoclassical traditions and continue to look for the leading causes of fundamental differences, through the role of institutional performance in NIE. This is essential for better economic development between states, regions, or locales in the world (Bashir, 2017; Madra, 2017; Prasetyo, 2020c). Furthermore, some economists claim that institutions play a critical role in economic development (Bider, 2018).

Human capital and social resource factors are keys to creating institutional performance and developing new products, which subsequently encourage economic growth and entrepreneurial business competitiveness (Prasetyo, 2020c, 2019c). To strengthen competitive advantage, four pillars of capacity are needed, including human capital, social capital, institutions, and entrepreneurship, (Prasetyo, 2020b, 2019b). Productivity is the key to entrepreneurial competitiveness and 
economic growth (Prasetyo, 2020d, 2020f, 2019a). However, in the era of globalization and during the Covid-19 pandemic, research on social entrepreneurship and the creation of social value chains has become increasingly important. There is a need to investigate strategies for enhancing the real role of social entrepreneurship to achieve a greater economic contribution and prosperity (Kassim, 2020; Prasetyo, 2020e; Ali \& Haseeb, 2019). The initial insight and opportunities for evaluating and validating social value chains through research design and other study settings are critical (Kasim, 2020).

\section{Research Method}

\subsection{Design and data source}

This research was developed on both qualitative and quantitative descriptive models based on the VCA method and path analysis. It also used a multi-stage random sampling method for entrepreneurial households. The sample data sources included 125 entrepreneurial households covering various types of handicrafts, bamboo, batik, embroidery, shuttlecock, doormat, water hyacinth, food, hair, and startup businesses. This technique is quite expensive and complex because it includes special sampling clusters. However, since this research is demanding, the benefits of the technique remain enormous. Specifically, this study explains the changing role of supply chains in value chain strategies to gain an entrepreneurial competitive advantage. The novelty and urgency of this analysis method are more focused on describing the creation of value chains in the supply chain through managerial decisions that integrated and collaborated with the role of related institutional performance. Furthermore, the VCA model aims to obtain higher profits through efficient use of resources and achieving entrepreneurial competitive advantage. The originality of the research method provides a unique insight into the creation of the NPD value chain, particularly in the local entrepreneurial business sub-sector. In general, the VCA method can be both qualitative and quantitative. There are no strict rules about how this should be carried out (Hellin, 2006; Zamora, 2016). A qualitative approach is used before a quantitative inquiry. In this study, the VCA dimension is based on the supply chain management (MSC) approach in a more complex and qualitative descriptive sub-sector. This method was used during data survey activities in a strict, thorough, and careful manner through observations, semistructured interviews, and focus group discussions (FGD). The questionnaire was tested and found to be valid. Hence, there is a need to build an understanding of the structure of path analysis more quantitatively. The purpose of value chain management is to add value by segmenting markets from a variety of different NPDs, designed to increase the profitability and competitive advantage of entrepreneurship based on local wisdom.

In this study, a quantitative aspect of VCA was integrated into the path analysis when the data survey and observation were conducted; therefore, the technique cannot be scientifically used again. Methodologically, the dimension of this work is more descriptive qualitative. Path analysis explains various factors that influence entrepreneurial competitive advantage both in a pathway strategy, directly and indirectly, as well as the total influence.

\subsection{Empirical analysis model}

The primary analysis model used in this study is path analysis, along with the VCA method. The approach explains the strategic path of institutional performance on the NPD value chain to improve entrepreneurial competitive advantage. The basic framework for this path analysis method uses three main resource factors, including human capital $\left(\mathrm{X}_{1}\right)$, social capital $\left(\mathrm{X}_{2}\right)$, and NPD $\left(\mathrm{X}_{3}\right)$. These factors affect product growth $\left(\mathrm{Y}_{1}\right)$ generated by entrepreneurship. Furthermore, the contribution of institutional performance $\left(\mathrm{Y}_{2}\right)$ in the local area emerged and collaborated with managers to improve entrepreneurial competitive advantage $(\mathrm{Z})$. Before describing the path analysis diagram model, its structural basic model equations need to be developed first. The model is made based on the standard linear regression equation of ordinary least squares (OLS), as shown below.

$$
\begin{aligned}
& Y_{1}=\rho_{Y 1} \cdot X_{1}+\rho_{Y 1} \cdot X_{2}+\rho_{Y 1} \cdot X_{3}+\varepsilon_{1} \\
& Y_{2}=\rho_{Y 2} \cdot X_{1}+\rho_{Y 2} \cdot X_{2}+\rho_{Y 2} \cdot X_{3}+\rho_{Y 2} \cdot Y_{1}+\varepsilon_{2} \\
& Y_{2}=\rho_{Z} \cdot X_{1}+\rho_{Z} \cdot X_{2}+\rho_{Z} \cdot X_{3}+\rho_{Z} \cdot Y_{1}+\rho_{Z} \cdot Y_{2}+\varepsilon_{3}
\end{aligned}
$$

The description of a path analysis strategy is shown in Fig. 1.

\section{Results and Discussion}

The path analysis results have been used as reference material for discussion include standardized coefficients beta values, as shown in Table 1. In model-1, the positive and significant role of the human capital (HC) resource factor provides the first largest contribution to entrepreneurial product growth (PG). The results are in line with previous research, which stated that human capital is the main determinant in local economic development (Azmi et al., 2018). This means that the existence and success of regional entrepreneurial businesses are still dependent on human capital resources. Furthermore, the NPD resource factor has the second-largest contribution to product growth. However, the existence of the NPD factor makes it unique. Although its existence is, on average, less than $50 \%$ of the total products produced, the growth value of this new product tends to be more progressive with the most significant increase. 


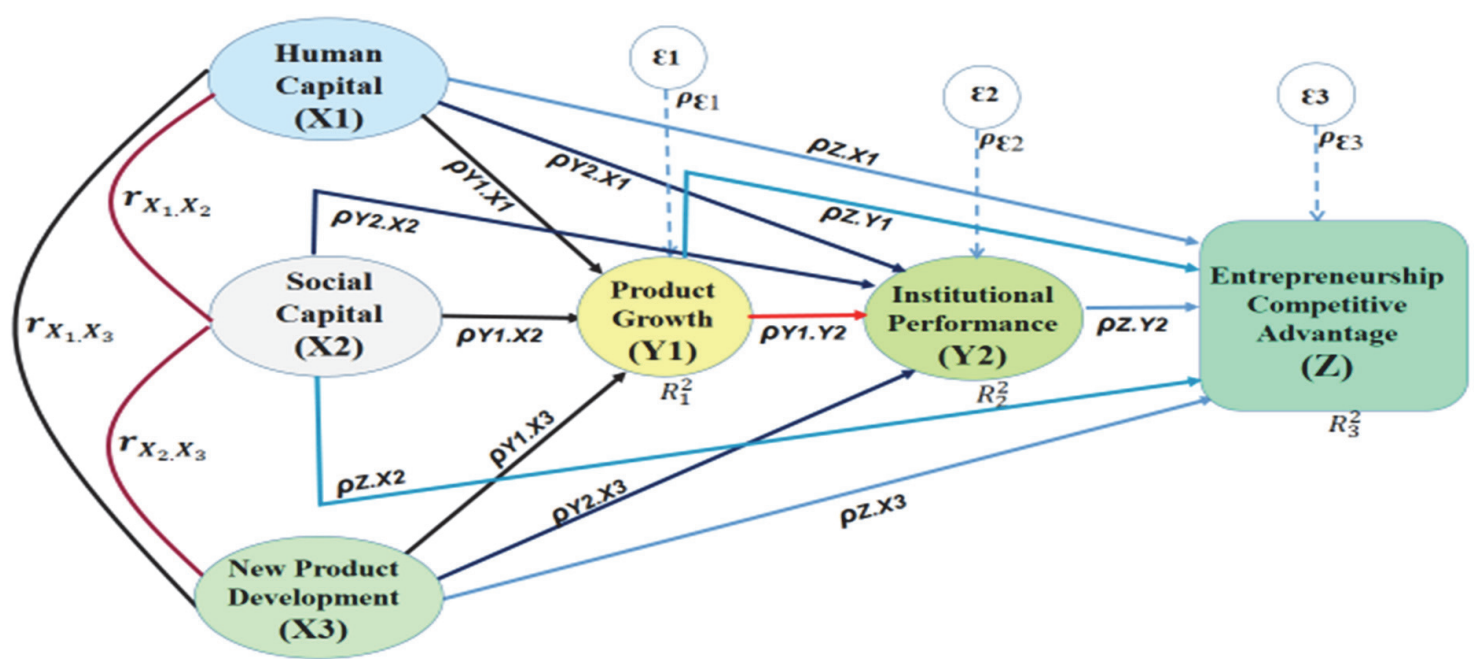

Fig. 1. Method of path analysis model with correlations in multiple path recursive form

In most studies with the VCA model, progressive growth provides a primary positive signal to entrepreneurial managers and related institutional performance in the local area to segment the product market separately. Consequently, related institutions in the region carry out effective policy interventions and collaborate with entrepreneurial managers to identify the new product. The aim is to increase the competitiveness of entrepreneurial businesses and their regions. This is because the progress and competitiveness of the regions depend on the capacity of the entrepreneurial industry. Furthermore, the effects of institutional policy interventions have a positive socio-economic impact on the local community. Critical notes and quantitative empirical evidence from the research on the surrounding community can be compared to the contribution value of social capital resources increasing from model-1, 2, and 3. This assertion is in line with previous research, which stated that the value chain provides job and market opportunities holistically for the poor, and small scale farmers. Model2 shows that positive and significant NPD resource factor has the first and largest contribution on institutional performance with $41.0 \%$. These results provide tangible evidence of the NPD value chain strategy adopted by entrepreneurial managers with institutional performance. The NPD has increased the value of social and economic life in the local community. It has also improved profits and has encouraged entrepreneurs to continue running their businesses. Furthermore, a combination of these two benefits can be pursued to achieve an entrepreneurial competitive advantage. The results also show there is a causal relationship between institutional performance and NPD in increasing entrepreneurial competitiveness.

Table 1

The multiple linear regression analysis results of the path analysis model in the form of OLS

\begin{tabular}{|c|c|c|c|c|c|c|}
\hline \multirow{2}{*}{\multicolumn{2}{|c|}{ Model }} & \multicolumn{2}{|c|}{ Unstandardized } & \multirow{2}{*}{$\begin{array}{c}\text { Standardized } \\
\text { Beta }\end{array}$} & \multirow{2}{*}{ t-stc. } & \multirow{2}{*}{ Sig. } \\
\hline & & B & Std. Error & & & \\
\hline \multirow{4}{*}{1} & (Constant) & -.027 & .030 & & -.922 & .358 \\
\hline & Human Capital (HC) & .501 & .062 & .485 & 8.040 & .000 \\
\hline & Social Capital (SC) & .193 & .068 & .171 & 2.820 & .006 \\
\hline & New Product Development (NPD) & .342 & .060 & .349 & 5.661 & .000 \\
\hline \multicolumn{7}{|c|}{ Product Growth $=0.485(\mathrm{HC})+0.171(\mathrm{SC})+0.349(\mathrm{NPD})+\varepsilon_{1 \&} \mathrm{R}^{2}=0.846 ; \mathrm{Dw}=2.176$} \\
\hline \multirow{5}{*}{2} & (Constant) & .143 & .019 & & 7.320 & .000 \\
\hline & Human Capital (HC) & .286 & .051 & .353 & 5.659 & .000 \\
\hline & Social Capital (SC) & .290 & .046 & .326 & 6.254 & .000 \\
\hline & New Product Development (NPD) & .315 & .044 & .410 & 7.085 & .000 \\
\hline & Product Growth (PG) & .039 & .060 & .050 & .648 & .518 \\
\hline \multicolumn{7}{|c|}{$\mathrm{IP}=0.353(\mathrm{HC})+0.326(\mathrm{SC})+0.410(\mathrm{NPD})+0.050(\mathrm{PG})+\varepsilon_{2 .} \& \mathrm{R}^{2}=0.897 ; \mathrm{Dw}=2.110$} \\
\hline \multirow{6}{*}{3} & (Constant) & -.107 & .029 & & -3.706 & .000 \\
\hline & Human Capital (HC) & .152 & .070 & .152 & 2.164 & .032 \\
\hline & Sosial Capital (SC) & .173 & .066 & .158 & 2.636 & .010 \\
\hline & New Product Development (NPD) & .286 & .065 & .302 & 4.378 & .000 \\
\hline & Product Growth (PG) & .172 & .073 & .178 & 2.343 & .021 \\
\hline & Institutional Performance (PI) & .309 & .113 & .250 & 2.741 & .007 \\
\hline
\end{tabular}

Source: Primary survey data. 
The NPD value chain strategy increases the role of the social capital resource factor, which initially contributed only $17.1 \%$ to $32.6 \%$. This leads to an increase in business profits. The comparison between models- 2 and -3 with model-1 shows that the NPD contribution is the most dominant effort for achieving entrepreneurial competitive advantage. Since NPD factors in models- 2 and 3 had the first and largest contribution of $41 \%$ and $30.2 \%$, respectively, the value chain strategy increases the profits and the entrepreneurial competitive advantage. However, product growth factors do not play significant roles in the institutional performance, though they have a positive effect on the entrepreneurial competitive advantage. The existing entrepreneurial business products are often imitated by rivals, making them less attractive and cheaper. The value chain strategy is focused only on NPD market segmentation. Although product growth has a positive role, its contribution is reduced and insignificant. When the product market situation is quiet, entrepreneurial managers often carry out a survival strategy with the system of "tuna satak bathi sanak"(Prasetyo, 2019d; Ngabalin, 2020). This is an appropriate aspect of local wisdom cultures in several research location areas. The survival culture supports the NPD value chain strategy developed when the business is facing many problems.

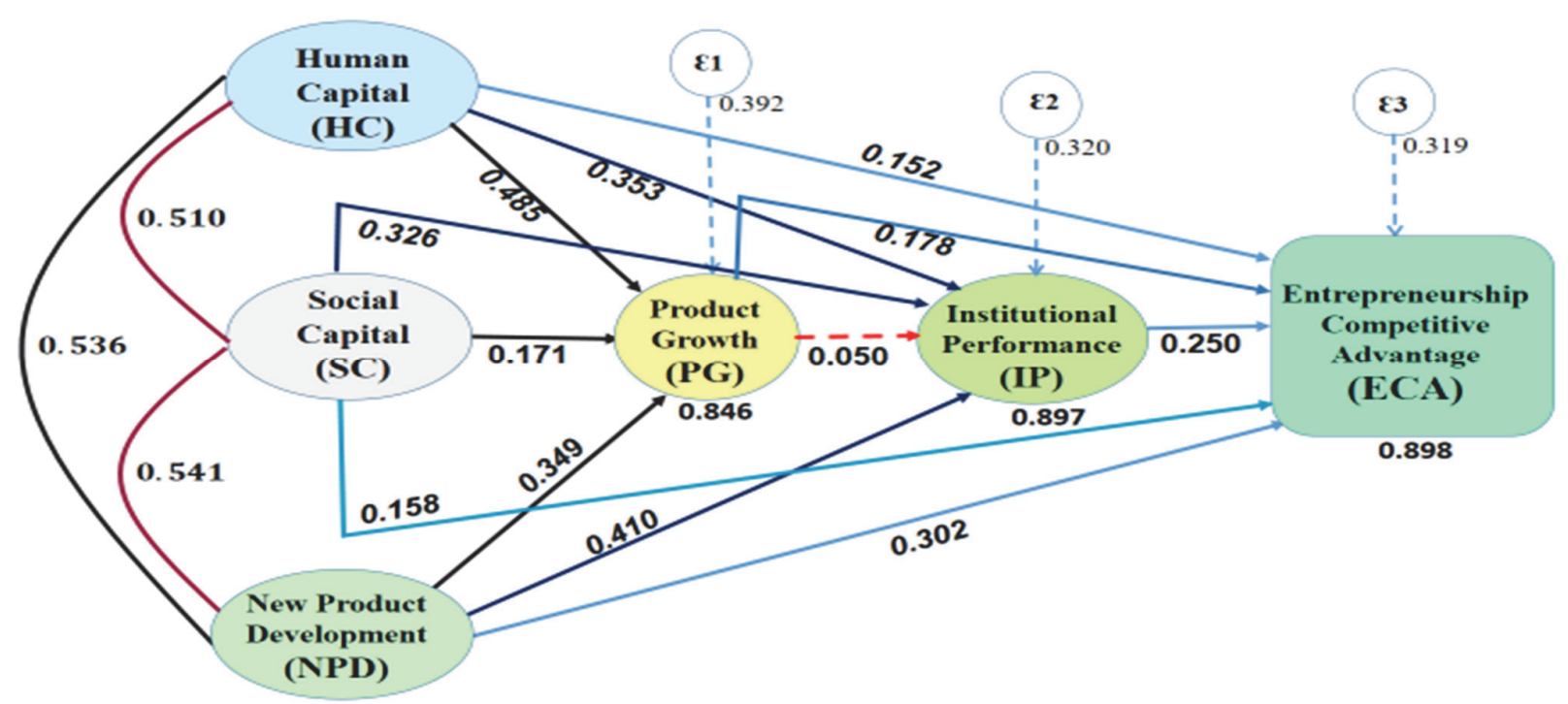

Fig. 2. The results of the path analysis model with the correlation of multiple path recursive forms

Table 1 in model 3 shows the positive and significant contribution of each resource factor towards the achievement of entrepreneurial competitive advantage in sequence from the largest as NPD, institutional performance, product growth, social capital, and human capital. The results of model-3 show that NPD has the first and the largest contribution to entrepreneurial competitiveness. However, the role of human capital resource factors is the smallest. The study shows that the NPD value chain strategy provides a change in the new role of resource use. Social capital is increasingly replacing the human capital factor. Therefore, there is a shared social responsibility from the integration and collaboration of supply and value chains between local entrepreneurial managers and related institutional performance. This is meant to improve the welfare of workers and the social community in their regions. Therefore, the NPD value chain changes the role and atmosphere of community life in the local area to be more humane.

In Fig. 2, the greatest correlation value between NPD and social capital is $54.1 \%$. This shows a strong, positive, and significant correlation between NPD and social capital resource factors. Likewise, there is a significant and positive relationship between NPD and human capital in supporting entrepreneurial competitive advantage. This shows that NPD is a smart product and connected throughout the value chain. However, it is still quite complex, hence there is a need for a new and compatible supporting technology infrastructure.

Table 2

Description of direct, indirect and total influence on entrepreneurial competitiveness

\begin{tabular}{ccccccccc}
\hline \multirow{2}{*}{ Variable } & $\begin{array}{c}\text { Direct } \\
\text { Influence }\end{array}$ & HC & SC & NPD & PG & IP & Sub Total & Total \\
Influence
\end{tabular}

Source: Primary data processed 
Table 2 shows that the NPD and institutional performance factors have a greater direct contribution to the achievement of the entrepreneurial competitive advantage. The magnitude of the first total influence is obtained from the NPD factor, which is $16.7 \%$ of the model's total effect by $51.5 \%$. The best value chain strategy can be formulated based on total influence value. Therefore, the best strategy should be initiated to manage NPD as a smart new product before other strategies.

The NPD value chain strategy has a role shifting effect. The increasing contribution of social capital factors has an impact on the diminishing role of the human capital resource. Empirically, this phenomenon is characterized by increasing opportunities for joint work and new markets in society. However, the human capital factor's total role is still the primary determinant, along with NPD and institutional performance in the model. There is a shift in function and role from direct to indirect influence without changing the structure and reducing the role of total influences from the human capital factor. Based on the new institutional economic theory (NIE), the institutional intervention policy carried out through the NPD value chain strategy model is effective.

\section{Conclusions and Recommendations}

The presence of intelligent new products that develop progressively challenge managers and related institutions to redesign and create the best strategy to remain effective. The role of value chains with a competitive advantage is well established. However, there is a need for new institutions, and various effective, efficient, and intelligent strategic alternatives for policy interventions. This is because the doctrine of neoclassical institutional economics is still considered inappropriate in conducting intervention for efficient social characteristics without changing existing social relations and structures. The use of NPD value chain strategy models makes new institutional theoretical contributions as a choice of progressive policy interventions. This is achieved by carrying out the NPD value chain strategy and identifying different market segments. These policy choices increase profits for managers and the community without changing the structure of resources that harms the role of existing human capital factors. Furthermore, the value chain strategy model provides new work opportunities for social communities in a holistic and humanistic manner.

It mutually supports efforts to achieve entrepreneurial competitiveness. Through NPD value chain strategy activities, entrepreneurial managers can still get additional benefits and better comfort. Therefore, the institutional intervention policy by carrying out NPD value chain strategy activities is the best and effective choice. The VCA research model is limited and tends to be qualitative, traditional, and linear, which is a major weakness in this study. Additionally, the study focuses more on forward linkages than backward linkages, specifically on the value chain rather than the supply chain. This means that even though the NPD value chain strategic model can be declared effective, it is scientifically inefficient. This research model still provides many new benefits and advantages for managers to improve their business competitiveness. To overcome this weakness, broader and more comprehensive research needs to be carried out with new approaches such as Value Grid. This enables managers to move beyond traditional linear thinking and map new opportunities and threats (Pil \& Holweg, 2006; Basheer et al., 2019).

\section{Acknowledgement}

The authors would like to thank the anonymous referees for constructive comments on earlier version of this paper. The authors also wish to thank the author institutionsthat have provided facilities and labotatories.

\section{References}

Abdullah, A., \& Senan, N. (2019). The complementary association between value chain analysis and target costing system to strengthen the competitiveness: An applied study on Saudi manufacturing companies in Al-Kharj. Management Science Letters, 9(10), 1543-1552.

Agboola, A.O. (2015). Neoclassical economics and new institutional economics. Journal Property Management, 5(1), 135.

Ali, A., \& Haseeb, M. (2019). Radio frequency identification (RFID) technology as a strategic tool towards higher performance of supply chain operations in textile and apparel industry of Malaysia. Uncertain Supply Chain Management, 7(2), 215-226.

Asheim, B., Grillitsch, M., \& Trippl, M. (2018). Unrelated knowledge combinations: the unexplored potential for regional industrial path development. Cambridge Journal of Regions, Economy and Society, 11, 257-274.

Azmi, F., Abdullah, A., Bakri, M., Musa, H., \& Jayakrishnan, M. (2018). The adoption of halal food supply chain towards the performance of food manufacturing in Malaysia. Management Science Letters, 8(7), 755-766.

Bashir, M., \& Verma, R. (2017). Why business model innovation is the new competitive advantage. Journal of Business Strategy, 14(1), 7-17.

Basheer, M., Siam, M., Awn, A., \& Hassan, S. (2019). Exploring the role of TQM and supply chain practices for firm supply performance in the presence of information technology capabilities and supply chain technology adoption: A case of textile firms in Pakistan. Uncertain Supply Chain Management, 7(2), 275-288.

Bider, D., Arzensek, M., \& Ferjancic, U. (2018). Institutions and economic development: A more complete view to understanding economic growth. Review of Economics \& Economic Methodology, 1, 70-87. 
Di Maria, E., De Marchi, V., \& Gereffi, G. (2019). Local clusters and global value chains. Handbook on Global Value Chains", Edward Elgar Publishing, 25, 403-416.

Doan, T. (2020). Supply chain management drivers and competitive advantage in manufacturing industry. Uncertain Supply Chain Management, 8(3), 473-480.

Ensign, P.C. (2001). Value chain analysis \& competitive advantage. Journal of General Management, 27(1), 18-42.

Gereffi, G., \& Lee, J. (2016). Economic and social upgrading in global value chains and industrial clusters: Why governance matters. Journal of Business Ethics, 133, 25-38.

Gereffi. G. \& Sturgeon, T. (2013). Global value chains and industrial policy: the role ofemerging economies. Fung Global Institute (FGI), WTO Publications, 329-360, 2013. Web site: www.wto.org

Grigorescu, I.L. (2015). Value chain analysis basic element of an organization competitive advantage. International Conference Knowledge Based Organization, 21(2), 318-324.

Hellin, J., \& Meijer, M. (2006). Guidelines for value chain analysis. Food and Argiculture Organization of the Uneted Nation.

IMA (Institute Management Accountants), (1996). Value Chain Analysis for Assessing Competitive Advantage. Institute of Management Accountants. 10 Paragon Drive Montvale, NJ. 07645-1760. www.imanet.org

Kassim, E.S., \& Habib M.M. (2020). Social enterprise and creation of social value chain. International Journal of Suply Chain Management, 9(2), 205-210.

Madra, Y.M. (2017). Late neoclassical economics: The restoration of theoretical humanism in contemporary economic theory. New Political Economy, 10(6), 47-77.

McDermott, J., \& Rich, K., (2010). Gebremendhin, B., \& Burrow, H. Value Chains and Innovation, $1^{\text {st }}$ ed., UFS and CTA. South Africa: Bloemfontein, 151-169.

Ngabalin, A. (2020). An Investigation on value chain cooperation attributes in fisheries micro-enterprises. Accounting, 6(3), 301-306.

OECD. (2013). Interconnected Economies: Benefiting from Global Value Chains. Synthesis Report. Available.

Pil, F.K., \& Holweg, M. (2006). Evolving from value chain to value grid. Mit Sloan Management Review, 47(4), 71-81.

Porter, M.E. \& Heppelmann, J.E. (2019). Why every organization needs an augmented reality strategy: The definitive management ideas of the year. Harvard Business Review, HBR'S 10 MUST, 10, 85-108.

Porter, M.E., \& Heppelmann, J.E. (2015). How smart, connected products are transforming companies. Harvard Business Review, 93(10), 96-114.

Porter, M.E. \& Kramer, M.R. (2011). Creating shared value. managing sustainable business. Harvard Business Review, 117.

Porter, M.E. (2000). Location, competition, and economic development: Local clusters in a global economy. Economic Development Quarterly, 14(1), 15-34.

Porter, M.E. (1998). "Clusters and the New Economics of Competition. Harvard Business Review, 76(6), 77-90.

Porter, M.E. (1985). Competitive Advantage-Creating a Sustaining Superior Performance, The Free Press: New York.

Prasetyo, P.E., Setyadharma, A., \& Kistanti, N.R. (2020a). New product development and institutional integration: Determinants of performance competitiveness progress. Entrepreneurship and Sustainability Issues, 8(1), 71-86.

Prasetyo, P.E., \& Kistanti, N.R. (2020b). Human capital, institutional economics and entrepreneurship as a driver for quality \& sustainable economic growth. Entrepreneurship and Sustainability Issues, 7(4), 2575-2589.

Prasetyo, P.E., Setyadharma, A., \& Kistanti, N.R. (2020c). The role of social capital in new products development and business competitiveness enhancement. International Journal of Scientific \& Technology Research, 9(3), $1838-1843$.

Prasetyo, P.E., (2020d). Human capital as the main determinant of regional economic growth. International Journal of Advanced Science and Technology, 29(3), 6261-6267.

Prasetyo, P.E. \& Kistanti, N.R. (2020e). Role of social entrepreneurship in supporting business opportunities \& entrepreneurship competitiveness. Open Journal of Business and Management, 8(3), 1164-1175.

Prasetyo, P.E. \& Dzaki, F.Z. (2020f). Efficiency performance and productivity of creative industries. International Journal of Advanced Science and Technology, 9(6), 122-132.

Prasetyo, P.E. (2019a). The reliability of entrepreneurial productivity as driver of economic growth and employment. International Journal of Entrepreneurship, 23(4), 1-15.

Prasetyo, P.E. Setyadharma, A., \& Kistanti, N.R. (2019b). The relationship between institutions and business opportunities toward economic growth. Economics Development Analysis Journal, 8(4), 281-291.

Prasetyo, P.E., \& Kistanti, NR. (2019c). The role of human capital in establishing new institutional economics and competitiveness. International Journal of Commerce and Management Research, 5(5), 64-70.

Prasetyo, P.E. (2019d). Role of entrepreneurial culture as the driver of economic growth. International Journal of Economics and Financial Issues, 9(3), 237-243.

Ridley, M. (2009). The importance of Value Chain Analysis (VCA) for understanding the globalization of production. International Political Economy, 5(1), 1-12.

Simatupang, T.M., Piboonrungroj, P., \& Williams S.J. (2017). The emergence of value chain thinking. International Journal of Value Chain Management, 10(Y), 1-18.

Steinhauser, D. (2014). The application of neoclassical economic theory and new institutional economic theory to creation of rules Corporate Governance. Conference Paper, Dolnozemská cesta, Bratislava, 852(35), 1-10.

Vijayan, G., Kamarulzaman, N.H., Mukherjee, A., \& Vaiappuri, S.K.N. (2016). Strategic Value Creation in a Supply Chain. Book Series, IGI Global, USA 17033. http://www.igi-global.com. 
Zamora, E.A. (2016). Value chain analysis: A brief review. Asian Journal of Innovation and Policy, 5(2), $116-128$.

Zhang, Y. (2014). Integrating SMEs into global value chains: policy principles and best practices. APEC Policy Support Unit, 1(6), 1-60.

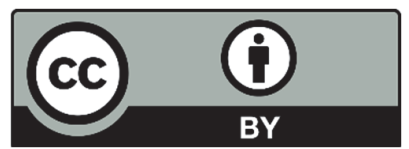

(C) 2020 by the authors; licensee Growing Science, Canada. This is an open access article distributed under the terms and conditions of the Creative Commons Attribution (CC-BY) license (http://creativecommons.org/licenses/by/4.0/). 